\title{
Study of Doppler indices of umbilical artery and middle cerebral artery in pregnancies at and beyond forty weeks of gestation
}

\author{
Subhra Ghosh $^{1} *$, Kirtirekha Mohapatra ${ }^{1}$, Sanjukta Samal $^{2}$, Pallabi Nayak ${ }^{1}$
}

\begin{abstract}
${ }^{1}$ Department of Obstetrics and Gynaecology, S.C.B. Medical College, Cuttack, Odisha, India
${ }^{2}$ Department of Obstetrics and Gynaecology, Harichandanpur C.H.C., Keonjhar, Odisha, India
\end{abstract}

Received: 10 October 2016

Accepted: 28 October 2016

\author{
*Correspondence: \\ Dr. Subhra Ghosh, \\ E-mail: subhraghosh66@yahoo.in
}

Copyright: (C) the author(s), publisher and licensee Medip Academy. This is an open-access article distributed under the terms of the Creative Commons Attribution Non-Commercial License, which permits unrestricted non-commercial use, distribution, and reproduction in any medium, provided the original work is properly cited.

\begin{abstract}
Background: The optimal management of pregnancies beyond date is still debated. Prolonged pregnancies carry risk to the fetus and routine induction increases the rate of primary cesarean section. Hence as there is evidence that placental reserve diminishes beyond term this study was conducted to know the effect of advanced gestation on Doppler indices and its correlation with perinatal outcome.

Methods: This prospective study was conducted on 80 pregnant women who are at or beyond 40 weeks of gestation. Doppler indices of umbilical artery and middle cerebral artery were taken. Data were analyzed with obstetrics and perinatal outcome.

Results: Umbilical artery mean RI increased with gestational age $(\mathrm{p}=0.003)$. There was no significant difference in PI and S/D ratio in different gestational age groups. Middle cerebral artery Doppler indices did not show any significant difference in different gestational age groups. In abnormal Doppler group, perinatal outcome was also not significantly different, but neonatal intensive care unit admission was increased, which was statistically significant $(\mathrm{p}=0.007)$.

Conclusions: Vascular resistance in the umbilical artery and middle cerebral artery does not change abruptly when gestation exceeds 280 days. It also cannot be taken as the sole method of fetal surveillance when date is crossed.
\end{abstract}

Keywords: Middle cerebral artery, Pulsatility index, Resistance index, S/D ratio, Umbilical artery

\section{INTRODUCTION}

ACOG has defined prolonged pregnancy as 42 weeks or more from the first day of last menstrual period. A late term pregnancy is defined as one that has extended beyond 41 weeks to 42 weeks. ${ }^{1}$ The incidence of post term pregnancy is about $5.5 \%$ of all pregnancies. ${ }^{1}$ Although risk factors like primigravida, previous post term pregnancy, male fetus, obesity, hormonal factors and genetic predisposition are identified, but when post term pregnancy truly exists, the cause is usually unknown post term pregnancy is associated with a number of complications and its prevention is not always possible. ${ }^{2-5}$ One retrospective study of over 1,70,000 singleton births using the appropriate denominator demonstrated a six fold increase in stillbirth rates in post term pregnancies from 0.35 to 2.12 per 1000 ongoing pregnancies. ${ }^{6} \mathrm{~A}$ study by Stotland demonstrated increased risk of stillbirth as pregnancy advances beyond 39 weeks. $^{7}$

The literature is inconsistent regarding both the type and frequency of antenatal surveillance. The morbidity and mortality in post dated pregnancies are thought to be the result of placental insufficiency, but data available in literature have yielded inconsistent results. ${ }^{8}$ Fetal death is reported with incidence of about 13 per 1000 in well assessed post term pregnancies. ${ }^{9}$

It has been postulated that the uteroplacental insufficiency is responsible for these problems. Thus, one could expect diminished uteroplacental flow, increased vascular resistance in the umbilical arteries and 
compensatory increased flow in fetal cerebral arteries in prolonged pregnancy as reported for placental insufficiency in growth retarded foetuses. ${ }^{10}$

The purpose of this study was to assess the effect of pregnancy beyond 40 weeks on the Doppler flow velocity waveforms in umbilical artery and middle cerebral artery and to correlate the flow velocity waveforms with perinatal outcome.

\section{METHODS}

This prospective observational study was conducted in the department of obstetrics and gynaecology, Sriram Chandra Bhanja Medical College, Cuttack from January 2013 to January 2015. All pregnant women at or beyond 40 weeks of gestation admitted to this department were selected for the study. Gestational age was established by the last menstrual period and confirmed by first trimester sonography. When a discrepancy of greater than seven days was detected, scan date was used to calculate the gestational age. Pregnancy with multifetal pregnancy, congenital anomalies and medical disorders like preeclampsia, renal diseases, cardiac diseases, GDM and Rh iso immunisation were excluded. Cases where induction of labour or caesarean section was planned were excluded from this study.

Cases were divided into three groups. Cases at 40 weeks of gestation were taken in group 1, cases beyond 40 weeks to 41 weeks in group 2 and cases more than 41 weeks of gestation were taken in group 3 .

Doppler examination was performed by two sonologists using GE Voluson P8 ultrasound machine.
For each examination, the mean value of three clear consecutive waveforms was recorded. The following variables were recorded.

1. Umbilical artery (UA) - RI, PI and S/D from a free loop of umbilical cord.

2. Middle cerebral artery (MCA) - RI, PI and S/D in the straight portion of the artery avoiding the head compression by the transducer.

These pregnant patients were followed up till delivery. Mode of delivery was noted in each case. Adverse perinatal outcome was evaluated when any of the following features was present.

1. Post maturity syndrome

2. Thick meconium stained liquor

3. Birth asphyxia

4. Neonatal intensive care unit admission

5. Intrauterine death or early neonatal death.

All the data were evaluated by SPSS (statistical package for social science, version 16.0). Proportions were compared by chi square test and ANOVA p test. In the present study, $\mathrm{p}<0.05$ was considered as the level of significance.

\section{RESULTS}

Table 1 shows age, parity and socio economic distribution of cases. The chi square test of association revealed that the three groups were more and less similar in these parameters.

Table 1: Socio-demographic features $(n=80)$.

\begin{tabular}{|c|c|c|c|c|c|c|c|c|c|}
\hline \multirow{2}{*}{ Features } & & \multicolumn{2}{|c|}{ GA 40 weeks } & \multicolumn{2}{|c|}{ GA > 40- 41weeks } & \multicolumn{2}{|c|}{ GA> 41 weeks } & \multirow{2}{*}{$\begin{array}{l}\text { Total } \\
\text { No }\end{array}$} & \multirow[t]{2}{*}{$\chi^{2}$ and $p$ value } \\
\hline & & No & $\%$ & No & $\%$ & No & $\%$ & & \\
\hline \multirow{3}{*}{ Age } & $<25$ & 14 & 33.3 & 21 & 50 & 7 & 16.7 & 42 & \multirow{3}{*}{$\begin{array}{l}\chi^{2}=1.057 \\
p=0.589\end{array}$} \\
\hline & $\geq 25$ & 9 & 23.7 & 23 & 60.5 & 6 & 15.8 & 38 & \\
\hline & Total & 23 & 28.8 & 44 & 55 & 13 & 16.2 & 80 & \\
\hline \multirow{3}{*}{ Parity } & Nulliparous & 13 & 24.1 & 32 & 59.3 & 9 & 16.7 & 54 & \multirow{3}{*}{$\begin{array}{l}\chi^{2}=1.829 \\
p=0.401\end{array}$} \\
\hline & Parous & 10 & 38.5 & 12 & 46.2 & 4 & 15.4 & 26 & \\
\hline & Total & 23 & 28.8 & 44 & 55 & 13 & 16.2 & 80 & \\
\hline \multirow{4}{*}{$\begin{array}{l}\text { Socio } \\
\text { economic } \\
\text { status }\end{array}$} & Lower & 18 & 32.1 & 28 & 50 & 10 & 17.9 & 56 & \multirow{4}{*}{$\begin{array}{l}\chi^{2}=1.893 \\
p=0.388\end{array}$} \\
\hline & Middle & 5 & 20.8 & 16 & 66.7 & 3 & 12.5 & 24 & \\
\hline & Upper & 0 & 0 & 0 & 0 & 0 & 0 & 0 & \\
\hline & Total & 23 & 28.8 & 44 & 55 & 13 & 16.2 & 80 & \\
\hline
\end{tabular}

Table 2 and 3 shows Doppler indices of umbilical artery in relation to different gestational age group that is 40 weeks, 40-41 weeks and beyond 41 weeks. The S/D ratio and $\mathrm{p}$ values showed no statistically significant difference, but the mean $\mathrm{R}$ increased which gestational age. The ANOVA indicated significant difference among the means $(\mathrm{p}=0.003)$. The pair wise multiple comparison also showed significant difference between groups. No cases in our study showed absent or reverse end diastolic flow in umbilical artery. 
Table 2: Comparison of Doppler indices of umbilical $\operatorname{artery}(\mathbf{n}=\mathbf{8 0})$.

\begin{tabular}{|c|c|c|c|c|}
\hline \multicolumn{2}{|c|}{ Umbilical artery } & Mean & SD & $\begin{array}{l}\text { ANOVA } \\
\text { 'p' value }\end{array}$ \\
\hline \multirow{4}{*}{$\begin{array}{l}\text { Umbilical } \\
\text { artery } \\
\text { S/D ratio }\end{array}$} & GA 40 weeks & 2.09 & 0.50 & \multirow{4}{*}{0.112} \\
\hline & $\begin{array}{l}\mathrm{GA}>40 \text { to } 41 \\
\text { weeks }\end{array}$ & 2.20 & 0.37 & \\
\hline & $>41$ weeks & 2.41 & 0.56 & \\
\hline & Total & 2.20 & 0.45 & \\
\hline \multirow{4}{*}{$\begin{array}{l}\text { Umbilical } \\
\text { artery } \\
\text { pulsatility } \\
\text { index }\end{array}$} & GA 40 weeks & 0.72 & 0.36 & \multirow{4}{*}{0.921} \\
\hline & $\begin{array}{l}\mathrm{GA}>40 \text { to } 41 \\
\text { weeks }\end{array}$ & 0.74 & 0.24 & \\
\hline & $>41$ weeks & 0.76 & 0.34 & \\
\hline & Total & 0.74 & 0.29 & \\
\hline \multirow{4}{*}{$\begin{array}{l}\text { Umbilical } \\
\text { artery } \\
\text { resistive } \\
\text { index }\end{array}$} & GA 40 weeks & 0.47 & 0.16 & \multirow{4}{*}{0.003} \\
\hline & $\begin{array}{l}\mathrm{GA}>40 \text { to } 41 \\
\text { weeks }\end{array}$ & 0.55 & 0.09 & \\
\hline & $>41$ weeks & 0.62 & 0.15 & \\
\hline & Total & 0.54 & 0.13 & \\
\hline
\end{tabular}

Table 4 and 5 analysed Doppler indices of middle cerebral artery. It was found that $\mathrm{S} / \mathrm{D}$ ratio; $\mathrm{P}$ and $\mathrm{R}$ do not differ significantly among the three groups. Multiple comparisons also revealed that there was no significant difference between any pair group with respect to any of these indices.

Table 6 compared umbilical artery S/D ratio which perinatal outcomes, but it failed to show any significant association $(\mathrm{p}=0.441)$.

Table 7 compared middle cerebral artery S/D ratio with perinatal outcome which also showed no significant association $(\mathrm{p}=0.867)$.

Table 8 compares perinatal outcome with Doppler indices. All cases with abnormal Doppler indices have undergone caesarean section. So there is statistically significant difference in mode of delivery in abnormal Doppler groups $(\mathrm{p}=0.011)$.

Table 3: Comparison of umbilical artery Doppler indices among the groups $($ Bonferroni) $(\mathbf{n}=\mathbf{8 0})$.

\begin{tabular}{|llllll|}
\hline Dependent variable & (I) GROUP & (J) GROUP & Mean difference (I-J) & S.E & P \\
\hline \multirow{2}{*}{$\begin{array}{l}\text { Umbilical artery S/D } \\
\text { ratio }\end{array}$} & GA 40 weeks & GA >40 to 41 weeks & -0.11 & 0.11 & 1 \\
\cline { 2 - 6 } & GA 40 weeks & GA>41 weeks & -0.32 & 0.15 & 0.111 \\
\cline { 2 - 6 } & GA > 40 to 41 weeks & GA >41 weeks & -0.21 & 0.14 & 0.381 \\
\hline $\begin{array}{l}\text { Umbilical artery } \\
\text { pulsatility index }\end{array}$ & GA 40 weeks & GA >40 to 41 weeks & -0.02 & 0.08 & 1 \\
\hline \multirow{2}{*}{$\begin{array}{l}\text { Umbilical artery } \\
\text { resistive index }\end{array}$} & GA 40 weeks & GA>41 weeks & -0.04 & 0.10 & 1 \\
\cline { 2 - 6 } & GA > 40 to 41 weeks & GA >41 weeks & -0.02 & 0.09 & 1 \\
\cline { 2 - 6 } & GA 40 weeks & GA >40 to 41 weeks & -0.07 & 0.03 & 0.063 \\
\hline
\end{tabular}

Table 4: Comparison of Doppler indices of middle cerebral artery $(n=80)$.

\begin{tabular}{|c|c|c|c|c|}
\hline \multicolumn{2}{|c|}{ Middle Cerebral Artery } & Mean & SD & ANOVA 'p' value \\
\hline \multirow{4}{*}{$\begin{array}{l}\text { Middle cerebral } \\
\text { artery S/D ratio }\end{array}$} & GA 40 weeks & 3.83 & 1.22 & \multirow{4}{*}{0.993} \\
\hline & $\mathrm{GA}>40$ to 41 weeks & 3.79 & 1.74 & \\
\hline & $\mathrm{GA}>41$ weeks & 3.81 & 1.38 & \\
\hline & Total & 3.80 & 1.53 & \\
\hline \multirow{4}{*}{$\begin{array}{l}\text { Middle cerebral } \\
\text { artery pulsatility } \\
\text { index }\end{array}$} & GA 40 weeks & 0.96 & 0.37 & \multirow{4}{*}{0.616} \\
\hline & $\mathrm{GA}>40$ to 41 weeks & 1.18 & 1.50 & \\
\hline & GA $>41$ weeks & 0.88 & 0.34 & \\
\hline & Total & 1.07 & 1.14 & \\
\hline \multirow{4}{*}{$\begin{array}{l}\text { Middle cerebral } \\
\text { artery resistive } \\
\text { index }\end{array}$} & GA 40 weeks & 0.71 & 0.19 & \multirow{4}{*}{0.051} \\
\hline & GA $>40$ to 41 weeks & 0.61 & 0.18 & \\
\hline & GA $>41$ weeks & 0.72 & 0.22 & \\
\hline & Total & 0.66 & 0.20 & \\
\hline
\end{tabular}

While comparing perinatal outcome with Doppler indices, it was observed that more patients with normal
Doppler indices delivered healthy newborns compared to cases with abnormal Doppler indices $(91.4 \% \mathrm{v} / \mathrm{s} 80 \%)$. But the difference is not statistically significant. 
Table 5: Comparison of Doppler indices of middle cerebral artery among groups $($ Bonferroni) $(\mathbf{n}=\mathbf{8 0})$.

\begin{tabular}{|c|c|c|c|c|c|}
\hline Dependent variable & (I) Group & (J) Group & Mean difference (I-J) & S.E & $\mathbf{P}$ \\
\hline \multirow{3}{*}{$\begin{array}{l}\text { Middle cerebral artery } \\
\text { S/D ratio }\end{array}$} & GA 40 weeks & $\mathrm{GA}>40$ to 41 weeks & 0.05 & 0.40 & 1 \\
\hline & GA 40 weeks & $\mathrm{GA}>41$ weeks & 0.03 & 0.54 & 1 \\
\hline & $\mathrm{GA}>40$ to 41 weeks & GA $>41$ weeks & -0.02 & 0.49 & 1 \\
\hline \multirow{3}{*}{$\begin{array}{l}\text { Middle cerebral artery } \\
\text { pulsatility index }\end{array}$} & GA 40 weeks & GA $>40$ to 41 weeks & -0.22 & 0.29 & 1 \\
\hline & GA 40 weeks & $\mathrm{GA}>41$ weeks & 0.08 & 0.40 & 1 \\
\hline & $\mathrm{GA}>40$ to 41 weeks & GA >41 weeks & 0.30 & 0.36 & 1 \\
\hline \multirow{3}{*}{$\begin{array}{l}\text { Middle cerebral artery } \\
\text { resistive index }\end{array}$} & GA 40 weeks & GA $>40$ to 41 weeks & 0.10 & 0.05 & 0.126 \\
\hline & GA 40 weeks & $\mathrm{GA}>41$ weeks & -0.01 & 0.07 & 1 \\
\hline & $\mathrm{GA}>40$ to 41 weeks & GA > $>1$ weeks & -0.11 & 0.06 & 0.183 \\
\hline
\end{tabular}

Table 6: Comparison of UA S/D ratio by perinatal outcome $(n=80)$.

\begin{tabular}{|c|c|c|c|c|c|c|c|}
\hline \multirow{3}{*}{$\frac{\text { Umbilical }}{\text { artery S/D ratio }}$} & \multicolumn{6}{|c|}{ Perinatal Outcome } & \multirow[t]{3}{*}{$\chi^{2}, \mathbf{p}$ value } \\
\hline & \multicolumn{2}{|c|}{ Normal } & \multicolumn{2}{|c|}{ Adverse } & \multicolumn{2}{|c|}{ Total } & \\
\hline & No & $\%$ & No & $\%$ & No & $\%$ & \\
\hline Normal & 67 & 89.3 & 8 & 10.7 & 75 & 100 & \multirow{3}{*}{$\begin{array}{l}\chi^{2}=0.593 \\
p=0.441\end{array}$} \\
\hline Abnormal & 5 & 100 & 0 & 0 & 5 & 100 & \\
\hline Total & 72 & 90 & 8 & 10 & 80 & 100 & \\
\hline
\end{tabular}

Table 7: Comparison of MCA S/D ratio by perinatal outcome $(n=80)$.

\begin{tabular}{|c|c|c|c|c|c|c|c|}
\hline \multirow{3}{*}{$\begin{array}{l}\text { Middle Cerebral } \\
\text { Artery S/D } \\
\text { Ratio }\end{array}$} & \multicolumn{6}{|c|}{ Perinatal Outcome } & \multirow[t]{3}{*}{$\chi^{2}$, p value } \\
\hline & \multicolumn{2}{|c|}{ Normal } & \multicolumn{2}{|c|}{ Adverse } & \multicolumn{2}{|c|}{ Total } & \\
\hline & No & $\%$ & No & $\%$ & No & $\%$ & \\
\hline Normal & 52 & 89.7 & 6 & 10.3 & 58 & 100 & \multirow{3}{*}{$\begin{array}{l}\chi^{2}=0.028 \\
p=0.867\end{array}$} \\
\hline Abnormal & 20 & 90.9 & 2 & 9.1 & 22 & 100 & \\
\hline Total & 72 & 90 & 8 & 10 & 80 & 100 & \\
\hline
\end{tabular}

Table 8: Comparison of perinatal outcome vis-a-vis Doppler Impression $(\mathbf{n}=\mathbf{8 0})$.

\begin{tabular}{|c|c|c|c|c|c|c|c|c|}
\hline & & \multicolumn{6}{|c|}{ Doppler impressions } & \multirow{3}{*}{$\chi^{2}, \mathbf{p}$ value } \\
\hline & & \multicolumn{2}{|c|}{ Normal } & \multicolumn{2}{|c|}{ Abnormal } & \multicolumn{2}{|c|}{ Total } & \\
\hline & & No & $\%$ & No & $\%$ & No & $\%$ & \\
\hline \multirow{4}{*}{ Delivery mode } & Spontaneous & 11 & 15.7 & 0 & 0 & 11 & 13.8 & \multirow{4}{*}{$\begin{array}{l}\chi^{2}=9.351 \\
p=0.009\end{array}$} \\
\hline & Induced & 25 & 35.7 & 0 & 0 & 25 & 31.2 & \\
\hline & LSCS & 34 & 48.6 & 10 & 100 & 44 & 55 & \\
\hline & Total & 70 & 100 & 10 & 100 & 80 & 100 & \\
\hline \multirow{6}{*}{ Perinatal outcome } & Healthy & 64 & 91.4 & 8 & 80 & 72 & 90 & \multirow{6}{*}{$\begin{array}{l}\chi^{2}=8.889 \\
p=0.064\end{array}$} \\
\hline & IUD & 1 & 1.4 & 0 & 0 & 1 & 1.2 & \\
\hline & Early neonatal death & 3 & 4.3 & 0 & 0 & 3 & 3.8 & \\
\hline & Meconeum stain & 2 & 2.9 & 1 & 10 & 3 & 3.8 & \\
\hline & Birth asphyxia & 0 & 0 & 1 & 10 & 1 & 1.2 & \\
\hline & Total & 70 & 100 & 10 & 100 & 80 & 100 & \\
\hline \multirow{3}{*}{$\begin{array}{l}\text { Neonatal intensive } \\
\text { care unit admission }\end{array}$} & Yes & 10 & 14.3 & 5 & 50 & 15 & 18.8 & \multirow{3}{*}{$\begin{array}{l}\chi^{2}=7.326 \\
p=0.007\end{array}$} \\
\hline & No & 60 & 85.7 & 5 & 50 & 65 & 81.2 & \\
\hline & Total & 70 & 100 & 10 & 100 & 80 & 100 & \\
\hline
\end{tabular}

But while comparing neonatal intensive care unit admission, newborns of abnormal Doppler group showed statistically significant admission rates $(\mathrm{p}=0.007)$.

\section{DISCUSSION}

The influence of prolonged gestation on Dopple flow velocity waveforms has been investigated previously with different results. In our study 80 cases at and beyond 40 
weeks gestation were divided into three groups. Group-1 comprises of pregnancies at 40wks, Group-2 comprises of pregnancies between 40-41wks and Group-3 comprises of pregnancies beyond 41 weeks of gestation. The Dopple indices of uterine artery, middle cerebral artery and perinatal outcomes were compared among the three groups.

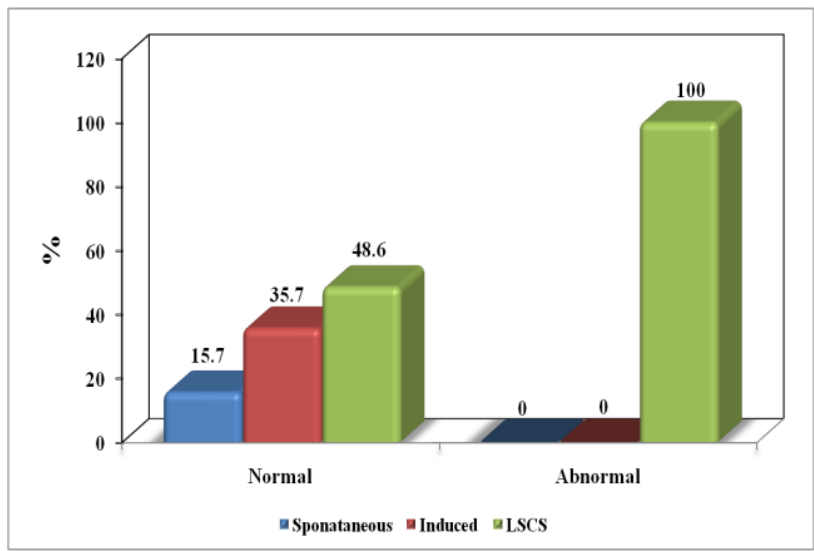

Figure 1: Comparison of delivery mode vis-a-vis Doppler impression.

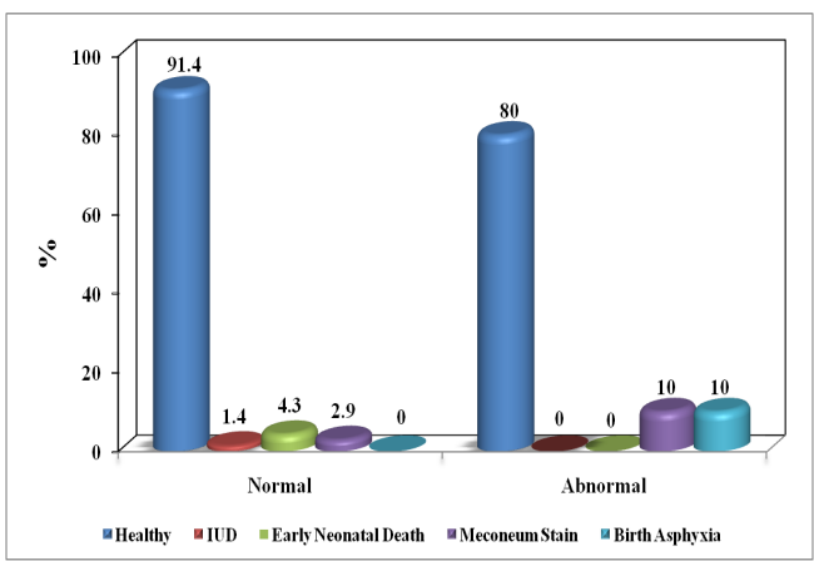

Figure 2: Comparison of perinatal outcome vis-a-vis Doppler impression.

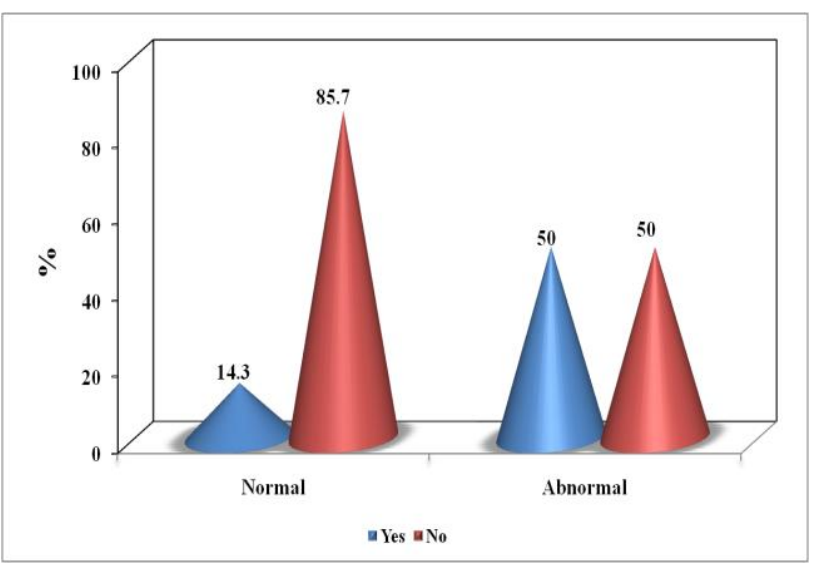

Figure 3: Comparison of neonatal intensive care unit admissions vis-a-vis Doppler impression.
In our study age, parity and socio economic status were more or less similar in all three groups with $\mathrm{p}$ value $0.589,0.401$ and 0.356 respectively.

The Doppler indices i.e. S/D, PI and RI of umbilical artery, middle cerebral artery did not show any statistically significant change as pregnancy advances from 40 wks to more than 41 weeks. But umbilical artery RI showed a significant increase when compared between group-1 and group-3 ( $\mathrm{p}=0.003)$. None of the cases found to have absent end diastolic flow or reversed end diastolic flow in umbilical artery Doppler study. Similar result was also obtained in the study by Zimmermann et al who reported that impedance to flow in umbilical artery and MCA did not change significantly as pregnancy advances from 41 weeks to 43 weeks of gestational age. ${ }^{11}$ BarHava et al in his study also found that there was no significant differences in Doppler indices in fetal umbilical, middle cerebral and renal arteries in pregnancies beyond 41 weeks and before 40 weeks, but Devine et al examined pregnancies at or more than 41 weeks of gestation and reported that decreased fetal middle cerebral artery and umbilical artery impedence to flow ratio is an accurate method of predicting adverse outcomes like cesarean delivery for fetal distress, fetal acidemia and meconeum aspiration syndrome. ${ }^{12,13}$

The incidence of cesarean section was $49.3 \%$ in normal Doppler group and $100 \%$ in abnormal Doppler group. The difference in mode of delivery is statistically significant in our study $(\mathrm{p}=0.011)$. Similar results was also found in the study by Marija T et al. ${ }^{14}$

In our study the doppler impression did not have any association with perinatal outcome. Similar result was also obtained by Stokes et al, who reported that impedance to flow in UA and MCA was not significantly different in pregnancies with abnormal fetal outcome compared to those with normal outcome. ${ }^{15}$ Although Marija $\mathrm{T}$ et al found perinatal complication more often in newborns of ladies who cross their EDD but the difference was not statistically significant. ${ }^{14}$ But our study showed that in abnormal Doppler group significantly more number of newborns required admission to neonatal intensive care unit.

\section{CONCLUSION}

The Doppler indices of UA and MCA arteries were studied in pregnancies at and beyond 40 weeks of gestation and correlated with perinatal outcome. There was no significant change in Doppler flow velocimetry. The impedence to flow in UA and MCA did not show any significant difference in pregnancies with abnormal fetal outcome from those with normal fetal outcome although NICU (neonatal intensive care unit) admission was increased in abnormal doppler group in our study. So we conclude that Dopple flow Velocimetry in UA and MCA did not show any correlation in pregnancies with abnormal fetal outcome in the present study group. Hence 
operative interference in cases of abnormal Doppler results in pregnancies beyond 40 weeks has to be reconsidered and other fetal surveillance tests are to be taken into consideration in these cases.

Funding: No funding sources

Conflict of interest: None declared

Ethical approval: The study was approved by the Institutional Ethics Committee

\section{REFERENCES}

1. American College of Obstetricians and Gynecologists. Practice bulletin no. 146: Management of late-term and post term pregnancies. Obstetrics and gynecology. 2014 Aug;124 (2 Pt 1):390.

2. Olesen AW, Westergaard JG, Olsen J. Perinatal and maternal complications related to postterm delivery: a national register-based study, 1978-1993. American Journal of Obstetrics and Gynecology. 2003;189(1):222-7.

3. Divon MY, Ferber A, Nisell H, Westgren M. Male gender predisposes to prolongation of pregnancy. American journal of obstetrics and gynecology. 2002;187(4):1081-3.

4. Stotland N, Washington AE, Caughey A. Prepregnancy body mass index and length of gestation at term. American Journal of Obstetrics and Gynecology. 2006;195(6):110.

5. Laursen M, Bille C, Olesen AW, Hjelmborg J, Skytthe A, Christensen K. Genetic influence on prolonged gestation: a population-based Danish twin study. American journal of obstetrics and gynecology. 2004;190(2):489-94.

6. Hilder L, Costeloe K, Thilaganathan B. Prolonged pregnancy: evaluating gestation-specific risks of fetal and infant mortality. BJOG: An International Journal of Obstetrics \& Gynaecology. 1998;105(2):169-73.

7. Sutan R, Campbell D, Prescott GJ, Smith WC. The risk factors for unexplained antepartum stillbirths in Scotland, 1994 to 2003. Journal of Perinatology. 2010;30(5):311-8.
8. Vorherr H. Placental insufficiency in relation to postterm pregnancy and fetalpostmaturity: evaluation of fetoplacental function; management of the postterm gravida. American journal of obstetrics and gynecology. 1975;123(1):67-103.

9. Votta RA, Cibils LA. Active management of prolonged pregnancy. American journal of obstetrics and gynecology. 1993;168(2):557-63.

10. Mari G, Deter RL. Middle cerebral artery flow velocity waveforms in normal and small-forgestational-age fetuses. American journal of obstetrics and gynecology. 1992;166(4):1262-70.

11. Zimmermann P, Albäck T, Koskinen J, Vaalamo P, Tuimala R, Ranta T. Doppler flow velocimetry of the umbilical artery, uteroplacental arteries and fetal middle cerebral artery in prolonged pregnancy. Ultrasound in Obstetrics and Gynecology. 1995;5(3):189-97.

12. Bar-Hava I, Divon MY, Sardo M, Barnhard Y. Is oligohydramnios is postterm pregnancy associated with redistribution of fetal blood flow. American journal of obstetrics and gynecology. 1995;173(2):519-22.

13. Devine PA, Bracero LA, Lysikiewicz A, Evans R, Womack S, Byrne DW. Middle cerebral to umbilical artery Doppler ratio in post-date pregnancies. Obstetrics and Gynecology. 1994;84(5):856-60.

14. Tasić M, Lilić V, Milošević J, Antić V, Stefanović M. Placental insufficiency in pregnancy after 40th week of gestation. Actamedica Medianae. 2007;46(4):26-30.

15. Stokes HJ, Roberts RV, Newnham JP. Doppler flow velocity waveform analysis in postdate pregnancies. Australian and New Zealand journal of obstetrics and gynaecology. 1991;31(1):27-30.

Cite this article as: Ghosh S, Mohapatra K, Samal S, Nayak P. Study of Doppler indices of umbilical artery and middle cerebral artery in pregnancies at and beyond forty weeks of gestation. Int J Reprod Contracept Obstet Gynecol 2016;5:4174-9. 